\title{
The seductive logic of subtractive sustainability: reflections on sustainable socio-economic development
}

\author{
Author: Ynte K. van Dam
}

Q: What's the first thing you'd take out of a burning house?

A: The fire

(Pratchett, 1995)

\begin{abstract}
Aim: To discuss the drivers and impediments sustainability of social systems. Design / Research methods: Analysis of and reflections on the discussions on campus antifragility during the $4^{\text {th }}$ international conference on efficiency, sustainable business and sustainable economic development, hosted by WSB Wroclaw on May $13^{\text {th }} 2016$.

Conclusions / findings: (1) Lack of sustainability results from organisational culture or dominant logic rather than from primary activities; (2) Disequilibrium in organisational culture reflects a lack of congruence between formal and informal institutions; (3) Conflict between informal and formal institutions is a driver of change, unless the formal institutions are enforced as a core cultural value; (4) Sustainability and sustainable development in a turbulent environment should aim for organisational and cultural diversity.

Originality / value of the article: This discussion note shows that a good metaphor can generate new insights. Viewed in terms of organisational viability and antifragility it is not what is done, but how it is done that determines the sustainability of an organisation. This implies that the ends never justify the means. The discussion note shows that sustainable development requires a critical reflection on the formal institutions and governance systems that determine these means. Likewise sustainable marketing requires a critical reflection on market institutions.
\end{abstract}

Keywords: Diversity, institutions, organisational culture, sustainable History: received 2016-07-29, development corrected 2016-10-20, accepted JEL: B52, M14, Q01 2016-10-20 


\section{Introduction}

Theories and models are mere metaphors for understanding the complexities of the real world. Theories are a way of viewing reality. A theory, like a metaphor, may fit reality but by definition cannot be true, and therefore the relevant questions to ask about a theory are not related to its truth or its lack of truth (Box 1976). Correct and relevant questions about theories, models, and about metaphors in general, are whether or not they contribute to understanding phenomena, and especially whether they help in generating new insights on these phenomena. The important questions to ask of a theory are along the line of 'Does it work?'. And the ultimate test of the usefulness of a theory is whether new empirical evidence provides sufficient reason to disconfirm and reject the understanding and insights that are generated. If a theory is sufficiently disconfirmed in sufficiently different ways it makes sense to accept the limits of this specific metaphor and search for a new one to explain the unexplainable. If not there is hardly a reason to stop using it as long as it fulfils its purpose of contributing to understanding and the generation of new insights. During the $4^{\text {th }}$ international conference on efficiency, sustainable business and sustainable economic development, hosted by WSB Wroclaw on May $13^{\text {th }} 2016$, the guiding metaphor was multilevel antifragility of a university campus. In this discussion note I analyse whether this worked and generated new insights.

\section{Setting the stage}

Antifragility recently has been introduced as the capacity of a system to benefit from stressors, shocks, and other influences that ordinarily are harmful to a system (Taleb 2012a, $2012 b)$. Antifragility therefore is the capacity of a system to gain order from disorder. In practical sense it remains unclear whether this benefit or gained order stems from an evolutionary weeding out of fragile subsystems (like in a species), from purposeful system learning (like in business), or from a reinforcing response (like in the body), just like it remains unclear at what level of system-analysis antifragility becomes an issue (Geddes 2012). Even if antifragility cannot be equated to the capacity of a system to live up to the epitome 'wat does not kill me, makes me stronger' (Geddes 2012, Nietzsche 1889), antifragility only is a relative and indeterminate state because only the lack of antifragility, i.e. 'whatever destroys me does kill me', can be positively and conclusively observed. All systems that currently seem to benefit from external stress are at best 'tentatively antifragile until proven differently'. The ultimate irony of positivist science is that in order to gain conclusive knowledge about something it is most often necessary to destroy it. This notwithstanding, because only the lack of antifragility can be conclusively observed, and because it is seriously doubted that antifragility can exist (Kovalenko, Sornette 2013), antifragility seems to be a fitting metaphor for sustainability (Jickling 1992).

Discussing sustainability of society in terms of campus antifragility with a group of academics (professors and students) is refreshing in several ways. It rapidly becomes evident that all four key concepts (society, campus, sustainability, and antifragility) are floating signifiers (Lévi-Strauss 1950) that lack a clear and unambiguous referent, and that have no concrete operational meaning. Even this limited domain does not allow for consensus - though to be fair, consensus among academics is rare under the best of circumstances. The meaning of sustainable development only becomes 


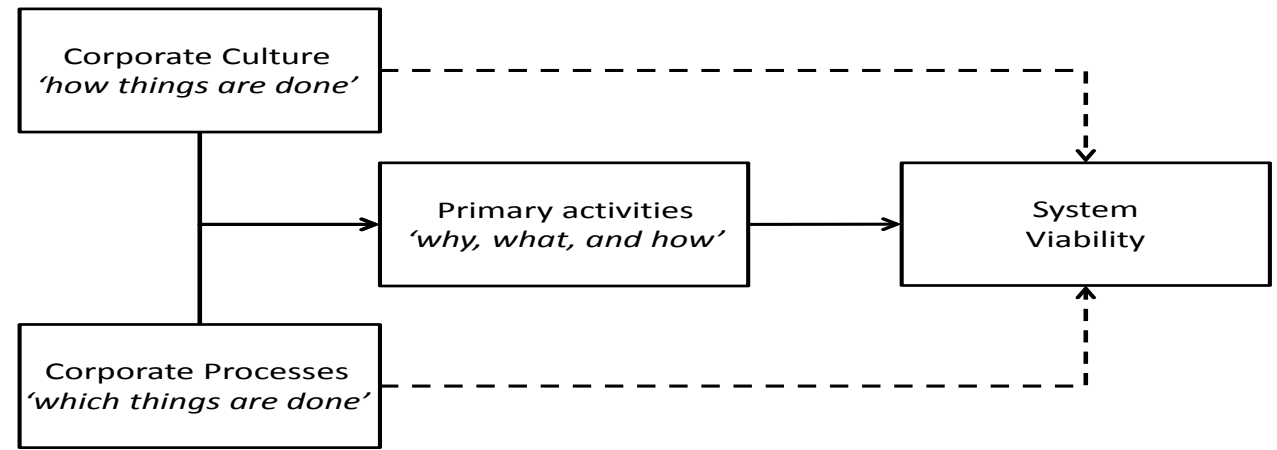

Figure 1: Proposed determinants of system viability

evident when applied to a specific concrete context and when discussed in terms of what changes are required to increase sustainability (or to decrease the lack of sustainability) in this concrete contextual application (Shearman 1990, Van Dam, Apeldoorn 1996). Likewise the meaning of 'campus' appears to become evident when applied to a specific and concrete issue. What is often referred to as an academic community, or Gesellschaft, rapidly turns out to be an academic society, or Gemeinschaft (Tönnies 1887).

\section{Playing the play}

The seminar was organised to elicit elements that contribute to the fragility of the (academic) system and to find ways to eliminate these. Without going into detail about the specific elements that were listed in this specific context, the elicited elements could be classified in two different ways. The first classification follows a distinction between primary elements (i.e. academic education and research), organisational elements (infrastructure and support) and resources (these latter are mostly financial). The second classification follows a distinction between process variables and culture variables. Structurally the result therefore can be depicted in a two-timesthree matrix. Process variables cover what is done, in terms of primary processes, organisational processes, and (financial) resource processes (Porter 1998). Culture variables cover how things are done (Balmer, Wilson 2001, Deshpande et al. 1993) in the primary, organisational and financial process. Functionally the variables may be grouped into three constructs: one covering corporate (organisational and financial) culture, one covering corporate (organisational and financial) processes, and one covering the primary activities (process and culture). Corporate processes support and corporate culture institutionalises the primary activities, and jointly they directly or indirectly determine system viability (Figure 1 ). This functional distinction is reminiscent of the distinction between technical (what) and functional (how) quality of services (Grönroos 1984). If services are substituted for the primary activities, then the quality of these primary activities has a technical and a functional component. The technical quality of the primary activities depends mainly on corporate processes and the functional quality depends mainly 
on corporate culture, whereas the synergy between processes and culture may further increase both quality components.

A striking observation is the general absence of reflective variables that cover why things are done the way they are done. Both the corporate processes and the corporate culture are assumed to be given, or at least they are not questioned, as a fact of life. Not questioning what is done and how it is done may have many benefits (Briley, Wyer Jr 2002) and increases the efficiency of an organisation (Alvesson, Spicer 2012), but it does not contribute to organisational survival in a volatile environment (Sørensen 2002). Even more disconcerting is this lack of critical reflection on corporate processes and corporate culture in a discussion of academic fragility among academics (Giroux 2011). This lack of critical reflection on the own organisation, even among academics, should be analysed to its sources and its consequences, though it is not too farfetched to assume that those consequences are related to antifragility/sustainability or the lack thereof (Cohan 2002).

A second observation is that corporate culture is a contested construct. Though there is little doubt about the influence of corporate culture on corporate performance (Deshpande et al. 1993, Sørensen 2002, Sugita, Takahashi 2015), and though there is at least qualitative evidence of the incorporation of sustainable values into corporate culture (McMaster 2003, Muja et al. 2014), the meaning of corporate culture remains elusive. The constituting elements and the underlying dimensions of corporate culture are not unambiguously operationalised and the relations between corporate culture and corporate performance are not unambiguously modelled (Balmer, Wilson 2001, Cameron, Quinn 2005, Dauber et al. 2012 Deshpande et al. 1993, Serpa 2016). A key issue in this context is whether culture explains why things are done or legitimises and prescribes how things are done (Dauber et al. 2012; Deshpande et al. 1993). In organisational and marketing literature these teleological and causal explanations are used interchangeably, mixing up or substituting ends with means, as is common in the praxeology of the Austrian school of economics (Von Mises 1949, 1962).

\section{Formal and informal culture}

Let corporate culture be a set of conventions that determine how things are done in a corporate organisation (Berry 2004, Cohan 2002). Corporate culture thus reflects the espoused values within an organisation and the conventional arrangements that coordinate individual actions within that organisation (Dauber et al. 2012, Hatch 1993, Schein 2006). It may be assumed that the informal culture and governance conventions are explicitly codified by the formal organisational culture and the formal governance style. This notwithstanding the formal codification is by necessity an abstraction (a theory or a model) of the informal culture and governance conventions. What is codified and made visible is a reduced slice of corporate reality that, like any formal contract, never covers all contingencies (Hart, Moore 1988). As long as this formal structure reflects the manifold informal structures, the formal structure may (appear to) function satisfactorily and the informal structures may remain invisible (Figure 2).

When formal institutions and formal governance styles are fully supported by the informal institutions an institutional equilibrium exists, and the informal institutions are the glue and grease that keep an organisation together and running (Platje 2008, 2011). In an institutional equilibrium the informal institutions compensate 


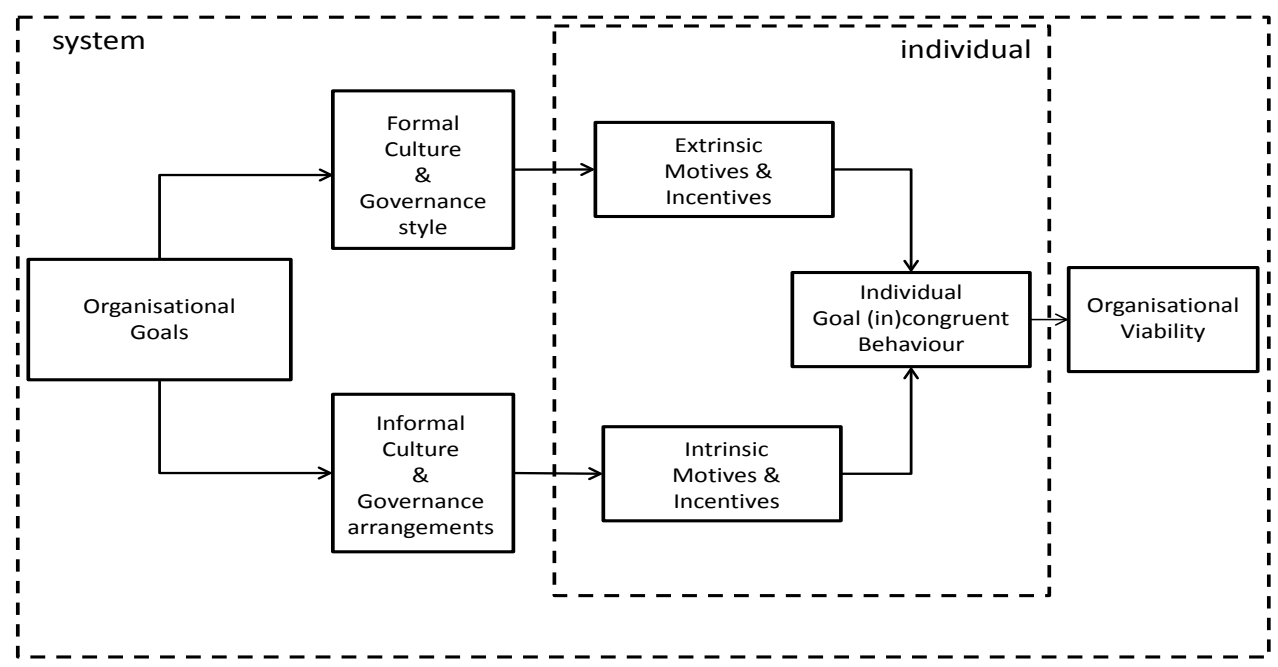

Figure 2: Culture, governance, and individual behaviour

for the incompleteness of the formal institutions. An unintended consequence is that the informal institutions cover for the misspecifications of the formal institutions, which enhances the perception of correctness and truth of the formal model. When the codified formal culture and governance style are mistaken for the underlying reality the abstract reduction sooner or later will be implemented to replace and curtail reality. This occurs in economic or organisational policy when the theory or the model is not used to understand social reality but to control and engineer this social reality, and the bureaucracy shifts from enabling into coercive (Adler, Borys 1996). In an informal organisation new entrants (employees, members or partners) must learn their way to understand the culture and the governance system in a trial-and-error process of integration and socialisation, which can be facilitated by informally showing the ropes (Sutton, Louis 1987). In a formal organisation the formal acculturation is codified in terms of 'this is how we do things around here', which covers the formal organisation but not necessarily the informal organisation from which this formal organisation has emerged (Banks 2008). After all, no model is correct and no formal arrangement can cover all eventualities that are taken for granted in an informal arrangement (Box 1976, Hart, Moore 1988) and likewise no formal acculturation can cover the full extent of the informal culture that makes an organisation run smoothly.

When the formal institutions and governance are not supported by the informal institutions, people are unwilling to comply with the formal rules and the informal culture increases friction and organisational costs (Platje 2008, 2011). Lack of acceptation of the formal culture may stimulate institutional change, but if the belief in the formal model is sufficiently strong it is more likely that the informal structures are 
viewed as 'aberrations of the model' or 'imperfections of the world' that are blamed for the decreased performance and viability of the formal system. Strong belief in the incompletely specified formal institutions easily results in a vicious circle as existing informal structures are eradicated and alternative non-formal structures spontaneously emerge to replace them, only to be eradicated by stricter rules and regulations once they become visible. Though the formal culture is supposed to be grounded in the informal culture, the two can easily get dissociated once the formal culture becomes codified and rationalised. Where formal physical models sooner or later are corrected by the physical world, because misspecified structures collapse, formal socio-economic models have a strong narrative component that allows their adherents to ignore corrections by the socio-economic world and instead make them try to bring the world in line with the model. It is a continuous source of surprise and wry amusement to observe how many laws and regulations have been necessary to safeguard and protect the 'self-regulating market' of classical economy (Polanyi 1944), or how many rules, regulations, forms, and bureaucrats are necessary to maintain 'bureaucratic efficiency' (Antonio 1979). Over the years the spontaneous resistance against (and consequent regulation of) the neo-liberal free market policy has been used as the decisive argument in favour of that policy, because 'if only the free market would be truly unregulated it would generate sustainable welfare as intended'. Likewise the bureaucracy would be efficient 'if only people would stick to the rules'.

\section{Subtractive epistemology and a culture of antifragility}

The general idea behind subtractive epistemology is creating improvements by elimination. This resembles the idea of incremental improvement by eliminating the worst evil, rather than salutary improvement by pursuing the greatest good (Popper 1945). The proposition is that if one eliminates what makes an organisation or a system fragile, the fragility would decrease and possibly the antifragility would increase. This proposition rests on a couple of hidden assumptions that can be illustrated by the model in Figure 2. A first assumption is that the formal knowledge of 'what makes a system tick' is accurate: if the formal knowledge is the belief in formal culture and governance style, the idea of subtractive epistemology forcibly suggests the elimination of the informal culture and governance arrangements that prevent the system to achieve its goals. This is more or less the argument that has always been and still is used by neo-liberal economists to demand a decrease in regulation of the market (Polanyi 1944, Von Mises 1949). Conversely if the formal knowledge embraces a strong belief in informal culture and spontaneous governance arrangements, the same idea of subtractive epistemology favours the radical elimination of the formal structure (Kropotkin 1927). Either might be successful and either might prove disastrous, and conclusive knowledge on what cannot be safely eliminated only results from positivist destruction of the system. Stepwise improvement by incremental elimination may turn into an elaborate game of organisational jenga. The key point, however, is that in most instances the identification of 'what makes an organisation fragile' depends on the ideology or the social paradigm of the observer.

A second assumption is that fragility is caused by the presence of something that can be eliminated. The generic organisation model of Figure 
2 presupposes a mutual reinforcement between formal and informal structures. Any organisation where formal structure is incongruent with the informal structure loses its viability. Subtractive epistemology suggests this can be solved by eliminating the absence of congruence rather than by the creation of congruence. Apart from the pragmatic observation that one cannot remove what is absent, this suggestion also ignores the institutional development processes by which the emergent formal culture and the informal culture may diverge. If the alienation of formal and informal culture is a consequence of the autonomous development of either culture, then the solution is not in dialectical elimination, but in a critical dialogue and synthesis between them.

\section{Final act}

Antifragility is simply defined as the capacity of a system to gain from disorder (Taleb 2012a). As long as it is not specified what the system should gain from disorder, it may be advisable not to push this metaphor too far. Antifragility as a goal implies that the primary aim of the system is survival, which seems rather shallow especially for functional systems like markets or organisations - though it may aptly describe the current state of the neo-liberal economic system. Antifragility as a condition appears to be a post hoc qualification of systems that have survived external stressors. Despite this obvious limitation, using the metaphor of antifragility in discussing campus sustainability may contribute to understanding sustainability, and especially to generating new insights on sustainability - if only because both sustainability and antifragility are unattainable in the current reality. So in this sense the metaphor may have worked in this seminar. Of course this does not mean it would work the same way for other people, and it does not mean that another metaphor might not have worked equally well or better.

A weak spot of the subtractive epistemology metaphor is similar to the problem of social costs in transaction cost economics (Coase 1960): irrespective the type and magnitude of social costs, sustainability increases with the internalisation and decreases with the externalisation of these costs. Lack of sustainability is caused by external costs, and in terms of subtractive epistemology sustainable development merely requires the elimination of external costs. Transaction costs economics shows that welfare effects are equal whether social costs are prevented or repaired afterwards, but this may be different for sustainability costs on two points. Firstly, the prevent/repair trade off assumes that reparation is possible, which may be a fallacy as convincingly shown in e.g. Bhopal (Eckerman 2005a, 2005b), or Chernobyl and Fukushima (Mietelski et al. 2014, Piedelievre et al. 1990). Secondly, contrary to the two-actor examples that are popular in transaction cost economics, in real life the externalised sustainability costs are too widely dispersed to be repaired, which implies that individual companies and their customers profit at the expense of current and future global population (Kapp 1971).

\section{Conclusion}

Viewed in terms of organisational viability and antifragility, the internal and external sustainability of an organisation depend on the interplay of technical-process variables (what is done) and functional-cultural variables (how things are done). Though much criticism on corporate sustainability refers to what companies do, the functional-cultural component of 
sustainability remains underrepresented. A functionalist view on sustainability therefore proposes that it is not what is done, but how it is done that determines sustainability. It is the means that determine the sustainability of the ends, but this implies that the ends do not justify the means. Critical analysis for sustainable development therefore should not primarily focus on the goals but on the procedures of an organisation: not 'why is this done?' but 'why is it done in this way?'.

If corporate culture and the means rather than ends of the organisation determine the sustainability of an organisation, the general lack of reflection on the formal culture and governance system that determine these organisational means is rather disconcerting. This lack of critical reflection has been explained as intentional organisational stupidity or as ethical blindness (Alvesson, Spicer 2012, Palazzo et al. 2012), which suggests a non-sustainable institutional equilibrium. Another explanation might be institutional disequilibrium and incongruence between the formal bureaucracy and the informal structures that has resulted in alienation and apathy among the members of this society (Abramson et al. 1978, Horton 1964, Seeman 1959, Weber 1922). The deeper explanation behind all these might be the that the dominant social paradigm, built around neo-classical economics and neo-liberalism, is so firmly established that it is beyond any critical discussion (Harris 2008, Kilbourne et al. 2009, Milburn, Harvie 2016).

Critical reflection on the concept of antifragility shows that at first glance it is incompatible with thermodynamics (Osband 2013), and therefore physically impossible in the physical universe as we know it. Critical reflection on the concept of sustainability shows that at first glance it is incompatible with the dominant social paradigm (Kilbourne et al. 2002), and therefore socially impossible in the social universe as we know it. A fundamental difference between the physical universe and the social universe, however, is that the former is indeed given as a fact of life whereas the latter only is assumed to be given but can be changed in principle. The discussion and reflection on campus antifragility shows that this change, though possible in principle, may never occur in practice due to institutional inertia. Feasibility of a change to sustainable development might be enhanced by focusing on the reduction of non-sustainable practices and damage prevention rather than on the increase of sustainable practices and damage repair. Of course this presupposes the ability to identify and critically evaluate non-sustainable practices, and the ability to find and implement alternative ways of doing things. Even though we do not know which path of development will eventually be sustainable, the subtractive epistemology of antifragility suggests that the sustainability of a system increases with the variability within that system (Fisher 1930). In a stable context the benefits of efficiency promote uniformity and homogeneity in a system, which implies that the fragility of that system in a turbulent context is increased. In order to prepare for sustainable development in a turbulent environment a system therefore should actively aim for organisational and cultural diversity in a stable environment, even (or especially) if this compromises efficiency. Sustainable development requires a critical reflection on the existing culture of governance and institutions, likewise sustainable marketing requires a critical reflection on market governance and institutions. 


\section{Bibliography}

Abramson L.Y., Seligman M.E., Teasdale, J.D. (1978), Learned helplessness in humans: critique and reformulation, "Journal of abnormal psychology", vol. 87, no. 1, p. 49.

Adler P.S., Borys B. (1996), Two types of bureaucracy: Enabling and coercive, "Administrative Science Quarterly", vol. 41, no. 1, pp. 61-89.

Alvesson M., Spicer A. (2012), A stupidity-based theory of organizations, "Journal of Management Studies", vol. 49, no. 7, pp. 1194-1220.

Antonio R.J. (1979), The contradiction of domination and production in bureaucracy: The contribution of organizational efficiency to the decline of the Roman Empire, "American Sociological Review", vol 44, no. 6, pp. 895-912.

Balmer J.M., Wilson A.M. (2001), Understanding organisational culture and the implications for corporate marketing, "European Journal of Marketing", vol. 35, nos. 3/4, pp. 353-367.

Banks J.A. (2008), Diversity, group identity, and citizenship education in a global age, "Educational Researcher, vol. 37, no. 3, pp. 129-139.

Berry B. (2004), Organizational culture: A framework and strategies for facilitating employee whistleblowing, "Employee Responsibilities and Rights Journal", vol. 16, no. 1, pp. 1-11.

Box G.E.P. (1976), Science and statistics, "Journal of the American Statistical Association", vol. 71, no. 356, pp. 791-799.

Briley D.A., Wyer Jr, R.S. (2002), The effect of group membership salience on the avoidance of negative outcomes: Implications for social and consumer decisions, "Journal of Consumer Research", vol. 29, no. 3, pp. 400-415.

Cameron K.S., Quinn R.E. (2005), Diagnosing and changing organizational culture: Based on the competing values framework, John Wiley \& Sons.

Coase R.H. (1960), The problem of social cost, "Journal of Law and Economics", vol. 3, no. 1, pp. 1-44.

Cohan J.A. (2002). "I didn't know" and "I was only doing my job": Has corporate governance careened out of control? A case study of Enron's information myopia, "Journal of Business Ethics", vol. 40, no. 3, pp. 275-299.

Dauber D., Fink G., Yolles M. (2012), A configuration model of organizational culture, "SAGE Open", vol. 2, no. 1, pp. 1-16.

Deshpande R., Farley J.U., Webster Jr, F.E. (1993), Corporate culture, customer orientation, and innovativeness in Japanese firms: a quadrad analysis, "The journal of Marketing", pp. 23-37.

Eckerman I. (2005a), The Bhopal gas leak: Analyses of causes and consequences by three different models, "Journal of Loss Prevention in the Process Industries, vol. 18, no. 4, pp. 213-217.

Eckerman I. (2005b), The Bhopal saga: causes and consequences of the world's largest industrial disaster, Universities press, Hyderabad.

Fisher R.A. (1930), The genetical theory of natural selection, Clarendon Press, Oxford.

Geddes L. (2012), Antifragil: how to make an unstable world strong. interview with Nassim Nicholas Taleb, 
"New Scientist", vol. 14 November 2012.

Giroux H.A. (2011, Tuesday, 18 January 2011), Beyond the swindle of the corporate university: Higher education in the service of democracy, Truthout.

Grönroos C. (1984), A service quality model and its marketing implications, "European Journal of Marketing", vol. 18 , no. 4 , pp. 36-44.

Harris H. (2008), Promoting ethical reflection in the teaching of business ethics, "Business ethics: A European review", vol. 17, no. 4, pp. 379-390.

Hart O., Moore J. (1988), Incomplete contracts and renegotiation, "Econometrica: Journal of the Econometric Society", vol. 56, no. 4, pp. 755-785.

Hatch M.J. (1993), The dynamics of organizational culture, "Academy of Management Review", vol. 18, no. 4, pp. 657-693.

Horton J. (1964), The dehumanization of anomie and alienation: a problem in the ideology of sociology, "The British Journal of Sociology", vol. 15, no. 4, pp. 283-300.

Jickling B. (1992), Viewpoint: Why I don't want my children to be educated for sustainable development, "The Journal of Environmental Education", vol 23, no. 4, pp. 5-8.

Kapp K.W. (1971), The social costs of private enterprise, 2nd ed., Schocken books, New York.

Kilbourne W.E., Beckmann S.C., Thelen E. (2002), The role of the dominant social paradigm in environmental attitudes: A multinational examination, "Journal of Business Research", vol. 55, no. 3, pp. 193-204.
Kilbourne W.E., Dorsch M.J., McDonagh P., Urien B., Prothero A., Grünhagen M., et al. (2009), The institutional foundations of materialism in western societies, "Journal of Macromarketing", vol. 29, no. 3, pp. 259-278.

Kovalenko T., Sornette, D. (2013), Dynamical diagnosis and solutions for resilient natural and social systems, “Planet@Risk”, vol. 1, no. 1, pp. 7-33.

Kropotkin P. (1927), Anarchism: A collection of revolutionary writings, Courier Corporation, North Chelmsford (Mass).

Lévi-Strauss C. (1950), Introduction à l'oeuvre de Marcel Mauss In: Marcel Mauss (1902 - 1938), Sociologie et anthropologie, PUF, Paris.

McMaster K.I. (2003), Not just another day on the job - Implementation of sustainable development in the minerals industry, "Exploration and Mining Geology", vol. 12, nos. 1-4, pp. 1-4.

Mietelski J.W., Kierepko R., Brudecki K., Janowski P., Kleszcz K., Tomankiewicz E. (2014). Long-range transport of gaseous $131 \mathrm{l}$ and other radionuclides from Fukushima accident to Southern Poland, "Atmospheric Environment", vol. 91, pp. 137-145.

Milburn K., Harvie D. (2016), On the uses of fairy dust: Contagion, sorcery and the crafting of other worlds, "Culture and Organization", pp. 1-17.

Muja N., Appelbaum S.H., Walker T., Ramadan S., Sodeyi T. (2014), Sustainability and organizational transformation: Putting the cart before the horse? (part two), "Industrial and Commercial Training", vol. 46, no. (6), pp. 307-314.

Nietzsche F. (1889), Götzen-Dämmerung oder wie man mit dem Hammer philosophirt, Verlag von C.G.Neuman, Leipzig. 
Osband K. (2013), Turbulence and evolutionary fitness, "Wilmott", 2013, no. 64 , pp. 8-11.

Palazzo G., Krings F., Hoffrage U. (2012), Ethical blindness, "Journal of Business Ethics", vol. 109, no. 3, pp. 323-338.

Piedelievre J.P., Musson-Genon L., Bompay F. (1990), MEDIA - an Eulerian model of atmospheric dispersion: first validation on the Chernobyl release, "Journal of Applied Meteorology", vol. 29, no. 12, pp. 1205-1220.

Platje J. (2008), An institutional capital approach to sustainable development, "Management of Environmental Quality", vol. 19, no. 2, pp. 222-233.

Platje J. (2011), Institutional capital creating capacity and capabilities for sustainable development, Wydawnictwo Uniwersytetu Opolskiego, Opole.

Polanyi K. (1944), The great ransformation: the political and economics origings of our time, Beacon Press, Boston.

Popper K. (1945), The open society and its enemies: part 1 The age of Plato, Routledge, London.

Porter M.E. (1998), The competitive advantage of nations, The Free Press, New York [etc.].

Pratchett T. (1995), Maskerade, Victor Gollancz Ltd., London.

Schein E.H. (2006), Organizational culture and leadership, John Wiley \& Sons, San Fransisco (CA).

Seeman M. (1959), On the meaning of alienation, "American Sociological Review", vol. 24, no. 6, pp. 783-791.

Serpa S. (2016), An overview of the concept of organisational culture, "International Business Management", vol. 10, no. 1, pp. 51-61.
Shearman R. (1990), The meaning and ethics of sustainability, "Environmental Management", vol. 14, no. 1, pp. 1-8.

Sørensen J.B. (2002), The strength of corporate culture and the reliability of firm performance, "Administrative Science Quarterly, vol. 47, no. 1, pp. 70-91.

Sugita M., Takahashi T. (2015), Influence of corporate culture on environmental management performance: An empirical study of japanese firms, "Corporate Social Responsibility and Environmental Management", vol. 22, no. 3, pp. 182-192.

Sutton R.I., Louis M.R. (1987), How selecting and socializing newcomers influences insiders, "Human Resource Management", vol. 26, no. 3, pp. 347-361.

Taleb N.N. (2012a), Antifragile. Things that gain from disorder, Penguin Books, London.

Taleb N.N. (2012b), Antifragile: how to live in a world we don't understand (vol. 3), Allen Lane, London.

Tönnies F. (1887), Gemeinschaft und Gesellschaft, Fues's Verlag, Leipzig.

Van Dam Y.K., Apeldoorn P.A.C. (1996), Sustainable marketing, "Journal of Macromarketing", vol. 16, no. 2, pp. 45-56.

Von Mises L. (1949), Human action a treatise on economics, Yale University Press, New Haven (CT).

Von Mises L. (1962), The ultimate foundation of economic science: an essay on method, D. Van Nostrand company, Princeton (NJ).

Weber M. (1922), Wirtschaft und Gesellschaft, Mohr, Tübingen. 


\title{
Kusząca logika zrównoważonego rozwoju subtraktywnego: refleksje na temat zrównoważonego rozwoju socjoekonomicznego
}

\begin{abstract}
Abstrakt
Cel: Omówienie czynników sprawczych i przeszkód zrównoważonego rozwoju systemów społecznych.

Metoda badawcza: Analiza i refleksje z dyskusji o antykruchości kampusu podczas Czwartej Międzynarodowej konferencji na temat sprawności, zrównoważonego rozwoju biznesu i zrównoważonego rozwoju ekonomicznego zorganizowanej w WSB we Wrocławiu, 13 maja 2016 r.

Wnioski: (1) Brak zrównoważonego rozwoju wynika raczej z kultury organizacyjnej lub dominującej logiki niż z aktywności podstawowych, (2) nierównowaga w kulturze organizacyjnej pokazuje brak zgodności między instytucjami formalnymi i nieformalnymi, (3) konflikt instytucji formalnych i nieformalnych jest czynnikiem wywołującym zmianę, chyba że instytucje formalne dominują jako podstawowa wartość kulturowa, (4) celem osiągniecia samopodtrzymującego i zrównoważonego rozwoju w niestabilnym środowisku jest dążenie do zróżnicowania organizacyjnego i kulturowego.

Oryginalność / wartość artykułu, wkład w rozwoju nauki: Ten artykuł pokazuje, że poręczna metafora może rodzić nowe spostrzeżenia. Z punktu widzenia żywotności organizacyjnej i zrównoważonego rozwoju, czynnikiem określającym samopodtrzymywalność organizacji nie jest to, co zostało wykonane, ale to, w jaki sposób zostało to wykonane. Takie ujecie tego problemu implikuje, że cele nigdy nie uświęcają środki. artykuł ponadto pokazuje, że zrównoważony rozwój wymaga krytycznej refleksji na temat instytucji nieformalnych i systemów współrządzenia, które te środki określają. Krytycznej refleksji na temat instytucji rynkowych wymaga również zrównoważony rozwój marketingu.
\end{abstract}

Słowa kluczowe: zróżnicowanie, instytucje, kultura organizacyjna, zrównoważony rozwój 